\title{
Pengaruh Penerapan Model Pembelajaran Group Investigation terhadap Pemahaman Konsep Matematis Ditinjau dari Kemampuan Awal Matematis Siswa MTs
}

\author{
M. Misrayanti dan Zubaidah Amir MZ \\ Program studi pendidikan matematika, Universitas Islam Negeri Sultan Syarif Kasim Riau \\ e-mail: zubaidah.amire@uin-suska.ac.id
}

\begin{abstract}
ABSTRAK. Adapun tujuan penelitian ini adalah untuk mengetahui ada tidaknya perbedaan pemahaman konsep matematis antara siswa yang mengikuti pembelajaran Group Investigation dengan siswa yang mengikuti pembelajaran langsung, ada tidaknya perbedaan pemahaman konsep matematis antara siswa yang mengikuti pembelajaran Group Investigation dengan siswa yang mengikuti pembelajaran langsung jika ditinjau dari kemampuan awal matematis, ada tidaknya pengaruh interaksi antara strategi pembelajaran dengan kemampuan awal matematis siswa terhadap pemahaman konsep matematis siswa. Populasi dalam penelitian ini adalah seluruh siswa kelas VIII Madrasah Tsanawiyah Darul Qur'an tahun ajaran 2016/2017. Sampel penelitian ini dipilih dengan menggunakan teknik purposive sampling, kelas VIII A sebagai kelas eksperimen dengan menggunakan model Group Investigation, kelas VIII B sebagai kelas kontrol dengan menggunakan pembelajaran langsung yang berjumlah 31 dan 25 orang siswa setiap masing-masing kelas. Data dianalisis dengan statistik deskriptif dan interpretasi. Teknik analisis data menggunakan uji-t dan anova dua arah (two factorial design). Instrumen yang digunakan adalah tes uraian untuk mengukur kemampuan awal dan kemampuan pemahaman konsep matematis siswa setelah perlakuan diberikan. Hasil penelitian menunjukkan bahwa terdapat pengaruh penerapan model pembelajaran Group Investigation terhadap kemampuan pemahaman konsep matematis siswa. Pengujian hipotesis menunjukkan bahwa terdapat perbedaan pemahaman konsep matematis antara siswa yang mengikuti pembelajaran Group Investigation dengan siswa yang mengikuti pembelajaran langsung, terdapat perbedaan pemahaman konsep matematis antara siswa yang mengikuti pembelajaran Group Investigation dengan siswa yang mengikuti pembelajaran langsung jika ditinjau dari kemampuan awal matematis, tidak terdapat pengaruh interaksi antara strategi pembelajaran dengan kemampuan awal matematis siswa terhadap pemahaman konsep matematis siswa.
\end{abstract}

Kata kunci: Model pembelajaran group investigation, kemampuan awal matematis, pemahaman konsep matematis

\section{PENDAHULUAN}

Matematika adalah salah satu mata pelajaran yang mempunyai pengaruh yang sangat penting, karena hampir semua ilmu pengetahuan terdapat unsur matematika. Matematika tidak hanya berupa simbol, tetapi matematika dapat melatih cara berpikir secara logis (masuk akal) siswa serta membantu memperjelas dalam menyelesaikan permasalahan. Matematika juga berfungsi mengembangkan kemampuan memecahkan masalah, kemampuan menyampaikan informasi atau mengkomunikasikan berbagai gagasan yang dapat dijelaskan melalui pembicaraan lisan, tulisan, grafik, peta, ataupun diagram.

Pada proses pembelajaran matematika umumnya masih banyak guru menerapkan model pembelajaran langsung (teacher center). Pembelajaran teacher centered dimana pembelajaran yang berlangsung bersifat searah akan membuat siswa selalu bergantung pada pekerjaan guru. Sehingga selama proses belajar mengajar siswa cenderung pasif saat mengikuti pelajaran matematika. Siswa mendengarkan, mencatat materi yang terkait, dan dituntut untuk menghafalkannya lalu siswa disuruh untuk mengerjakan latihan-latihan soal dengan rumus yang diberikan guru tanpa tahu akan 
tujuan dan manfaat yang akan mereka peroleh (Wina Sanjaya, 2006, p. 3). Hal ini mengakibatkan siswa hanya terbatas pada aktivitas mendengarkan penjelasan dari guru, mencatat, dan mengerjakan tugas. Sedangkan untuk aktivitas berdiskusi yang di dalamnya siswa dapat saling bertukar pendapat dalam suatu penyelidikan kasus tertentu jarang dilakukan.

Berdasarkan hasil observasi di Madrasah Tsanawiyah Darul Qur'an bahwa dalam setiap pembelajaran matematika siswa hanya tertuju pada materi yang sedang diajarkan saja dan pada pertemuan selanjutnya siswa lupa tentang materi yang telah dipelajari padahal materi itu ada hubungan. Jadi siswa biasanya hanya tertuju pada materi atau topik yang sedang dipelajari saja, topik atau materi sebelumnya dilupakan begitu saja karena dianggap sudah berlalu atau sudah tidak perlu lagi untuk diingat. Akibanya jika siswa dihadapkan dengan persoalan baru yang melibatkan topik lain biasanya mereka tidak bisa untuk menyelesaikan persoalan tersebut, bahkan memahami maksud pertanyaannyapun belum bisa. Selain itu kebanyakan siswa menganggap matematika itu merupakan pelajaran yang sulit, ini terbukti dari nilai ulangan harian siswa dan hasil ujian semester ganjil yang dibawah standar KKM. Kemudian pada saat pembelajaran matematika, apabila guru bertanya kepada siswa sudah paham atau belum siswa diam dan apabila guru bertanya ada yang mau ditanyakan siswa juga diam, disini terlihat bahwa keaktifan di ruang kelas kurang karena siswa kurang bertanya apabila belum paham, hanya sebagian siswa yang aktif bertanya tanpa ditunjuk oleh guru.

Untuk memperoleh kemampuan pemahaman konsep matematis yang baik dimungkinkan bila dalam proses pembelajaran siswa sebagai pelaku pembelajaran. Penelitian menunjukkan bahwa model dan strategi pembelajaran dapat digunakan untuk meningkatkan kemampuan pemahaman konsep. Pemahaman konsep dengan menggunakan model pembelajaran Quantum Teaching (Sari, Suhandri \& Nufus, 2018), kooperatif tipe kreatif-produktif (Wahidah, Hasanuddin \& Hartono, 2018), dan Couse Review Horay (Muhandaz, Trisnawita \& Risnawati, 2018).

Salah satu model pembelajaran yang menjadikan siswa sebagai pelaku pembelajaran adalah model pembelajaran Group Investigation. Dalam model pembelajaran Group Investigation siswa dituntut tidak hanya mempelajari materi saja. Namun, harus mempelajari keterampilanketerampilan khusus seperti keterampilan kooperatif. Keterampilan ini bertujuan untuk melancarkan hubungan satu sama lain dalam kerja, dan penyelesaian tugas. Peranan hubungan satu sama lain dalam kerja dapat diperoleh dengan mengembangkan informasi dan kerja sama satu sama lain dalam kelompok sedangkan peranan penyelesaian tugas dapat diperoleh dengan pembagian kelompok sehingga siswa dapat lebih aktif dan bertanggung jawab (Wina Sanjaya, 2006, p. 24).

Faktor lain yang juga menentukan keberhasilan siswa dalam menerima pelajaran adalah kemampuan awal. Kemampuan awal merupakan hasil belajar yang didapat sebelum mendapat kemampuan yang lebih tinggi. Kemampuan awal siswa merupakan prasyarat untuk mengikuti pembelajaran sehingga dapat melaksanakan proses pembelajaran dengan baik. Kemampuan seseorang yang diperoleh dari pelatihan selama hidupnya, dan apa yang dibawa untuk menghadapi suatu pengalaman baru.

Kemudian belajar akan lebih bermakna apabila materi yang dipelajari (hasil belajar berupa konsep atau prinsip) diasumsikan atau dihubungkan dengan pengetahuan yang telah dimiliki siswa dalam bentuk struktur kognitif berupa fakta-fakta, konsep-konsep dan generalisasi yang dipelajari atau diingat oleh siswa. Pembelajaran yang berorientasi pada pengetahuan awal akan memberikan dampak pada proses dan perolehan belajar yang memadai. Dari pendapat tersebut menjelaskan bahwa kemampuan awal merupakan elemen esensial untuk menciptakan proses pembelajaran menjadi sesuatu yang bermakna.

Berkaitan dengan uraian yang telah dikemukakan tersebut, maka peneliti tertarik untuk melakukan penelitian dengan judul Pengaruh Penerapan Model Pembelajaran Group Investigation terhadap Pemahaman Konsep Matematis ditinjau dari Kemampuan Awal Matematis Siswa Madrasah Tsanawiyah. 


\section{METODE}

Penelitian ini dilaksanakan di kelas VIII MTs Darul Qur'an yang beralamat di Kubang Raya Kabupaten Kampar, pada tahun 2017/2018 semester genap. Jenis penelitian yang dilaksanakan adalah quasi eksperimen, dimana kelompok kontrol tidak dapat berfungsi sepenuhnya untuk mengontrol variabel-variabel luar yang mempengaruhi pelaksanaan eksperimen (Sugiyono, 2012: 77). Desain yang digunakan adalah Randomized Pretest-Posttest Control Group Design. Penelitian eksperimen merupakan penelitian yang digunakan untuk mencari pengaruh perlakuan tertentu terhadap yang lain dalam kondisi yang terkendalikan. Dengan sampel yang terdiri atas 2 kelas yaitu kelas eksperimen dan kelas kontrol. Didalam strategi ini sebelum dimulai perlakuan, kedua sampel diberikan test awal atau pretest untuk mengukur kondisi awal atau untuk mendapatkan data awal. Selanjutnya pada kelompok eksperimen diberikan perlakuan $(X)$ dan kelompok kontrol tidak. Subjek dalam penelitian ini adalah siswa kelas VIII M'Ts Darul Qur'an.

Sedangkan objek dalam penelitian ini adalah pemahaman konsep matematis siswa dengan metode Group Investigation ditinjau dari kemampuan awal matematis siswa. Populasi dalam penelitian ini adalah seluruh siswa MTs Darul Qur'an Tahun ajaran 2016/2017 berjumlah 175 siswa, yang merupakan populasi umumnya. Sedangkan populasi targetnya adalah seluruh siswa kelasVIII di MTs Darul Qur'an berjumlah 56 siswa yang terdiri dari 2 kelasyaitukelas VIII A dan VIII B.Teknik pemilihan sampel yang digunakan dalam penelitian ini adalah teknik Purposive Sampling. Instrumen yang digunakan dalam penelitian ini adalah observasi, tes kemampuan awal, tes kemampuan pemahaman konsep. Teknik analisis data yang digunakan adalah analisis deskriptif kualitatif dan analisis deskriptif kuantitatif.

\section{HASIL DAN PEMBAHASAN}

Uji Pengaruh Interaksi Antara Model Pembelajaran dengan Kemampuan Awal Matematis Terhadap Pemahaman Konsep.

Tabel 9. Hasil Uji Interaksi

\begin{tabular}{|c|c|c|c|c|c|c|}
\hline $\begin{array}{l}\text { Sumber } \\
\text { Variansi }\end{array}$ & $\mathrm{Dk}$ & JK & RK & Fh & $\mathrm{Ft}$ & Kesimpulan \\
\hline $\begin{array}{l}\text { Antar kolom } \\
\text { (KAM) }\end{array}$ & 2 & 3943,56 & 1971,78 & 184,97 & $\begin{array}{l}3,1 \\
7\end{array}$ & $\begin{array}{l}\text { Terdapat pengaruh } \\
\text { faktor KAM } \\
\text { terhadap } \\
\text { kemampuan } \\
\text { pemahaman } \\
\text { konsep }\end{array}$ \\
\hline $\begin{array}{l}\text { Antar baris } \\
\text { (Model) }\end{array}$ & 1 & 910,17 & 910,17 & 85,38 & $\begin{array}{l}1,0 \\
2\end{array}$ & $\begin{array}{l}\text { Terdapat pengaruh } \\
\text { faktor model } \\
\text { pembelajaran } \\
\text { terhadap } \\
\text { kemampuan } \\
\text { pemahaman } \\
\text { konsep }\end{array}$ \\
\hline $\begin{array}{l}\text { Interaksi } \\
\text { KAM*Mode }^{*} \text { Mode }\end{array}$ & 2 & 58,80 & 29,40 & 2,76 & $\begin{array}{l}3,1 \\
7\end{array}$ & $\begin{array}{l}\text { Tidak terdapat } \\
\text { pengaruh interaksi } \\
\text { antara model } \\
\text { pembelajaran } \\
\text { dengan KAM } \\
\text { terhadap } \\
\text { kemampuan } \\
\text { pemahaman } \\
\text { konsep }\end{array}$ \\
\hline
\end{tabular}


Berdasarkan tabel dapat disimpulkan bahwa Faktor model pembelajaran memberikan pengaruh yang signifikan terhadap pemahaman konsep matematis. Hal ini terlihat dari nilai signifikan untuk strategi pembelajaran adalah 85,38. Faktor KAM juga memberikan pengaruh yang signifikan terhadap pemahaman konsep matematis. Hal ini terlihatdari nilai signifikan untuk KAM adalah 184,97. Untuk melihat ada atau tidaknya interaksi antara strategi pembelajaran dan KAM siswa terhadap kemampuan pemahaman konsep matematis, kriteria pengujian adalah jika signifikan $\mathrm{Fh}>\mathrm{Ft}$ maka hipotesis Ha diterima.

Tabel di atas memperlihatkan nilai Fh yang diperoleh adalah 2,76 dengan Ft 3,17. Hal ini berarti hipotesis yang menyatakan $\mathrm{Ha}$ ditolak dan Hoditerima. Ho diterima dapat disimpulkan bahwa "tidak terdapat efek/pengaruh interaksi antara strategi pembelajaran dengan kemampuan awal matematis siswa terhadap pemahaman konsep matematis siwa". Dengan kata lain pemahaman konsep matematis siswa karena pengaruh model pembelajaran tidak bergantung pada peringkat KAM siswa, dan pemahaman konsep siswa karena pengaruh peringkat KAM tidak bergantung pada penggunaan model pembelajaran. Dengan demikian analisis pasca Anova tidak dilanjutkan pada interaksi.

Berdasarkan hasil tes kemampuan pemahaman konsep matematis dapat diketahui bahwa siswa yang dalam pembelajarannya menggunakan model pemebelajaran Group Investigation memiliki rata-rata kemampuan pemahaman konsep matematis 73,87. Sedangkan siswa yang dalam pembelajarannya menggunakan model pembelajaran langsung memiliki rata-rata kemampuan pemahaman matematis 65,6 .

Berdasarkan uji hipotesiskitadapatkanbahwa: Terdapat perbedaan pemahaman konsep matematis antara siswa yang mengikuti pembelajaran Group Investigation dengan siswa yang mengikuti pembelajaran langsung.

Tabel 10. Data Pemahaman Konsep Matematis Siswa

\begin{tabular}{|c|c|c|c|c|c|}
\hline \multirow[t]{2}{*}{ No } & \multirow[t]{2}{*}{ Indikator } & \multicolumn{2}{|c|}{$\begin{array}{c}\text { Kelas } \\
\text { Eksperimen }\end{array}$} & \multicolumn{2}{|c|}{ Kelas Kontrol } \\
\hline & & $\overline{\bar{X}}$ & Kategori & $\overline{\bar{X}}$ & Kategori \\
\hline 1 & Menentukan unsusr-unsur kubus & 100 & Tinggi & 96 & Tinggi \\
\hline 2 & Menentukan unsur-unsur balok & 100 & Tinggi & 92 & Tinggi \\
\hline 3 & $\begin{array}{l}\text { Menentukan sifat-sifat kubus dan } \\
\text { balok }\end{array}$ & 55 & Rendah & 45 & Rendah \\
\hline 4 & $\begin{array}{l}\text { Menentukan luas serta volume pada } \\
\text { kubus dan balok }\end{array}$ & 56 & Rendah & 44 & Sedang \\
\hline 5 & $\begin{array}{l}\text { Menentukan penyelesaian luas serta } \\
\text { volume pada kubus dan balok }\end{array}$ & 75 & Sedang & 75 & Sedang \\
\hline 6 & $\begin{array}{l}\text { Menentukan perubahan volume pada } \\
\text { kubus dan balok }\end{array}$ & 93 & Tinggi & 79 & Sedang \\
\hline \multirow[t]{2}{*}{7} & $\begin{array}{l}\text { Menentukan penyelesaian } \\
\text { penerapankubus dan balok }\end{array}$ & 60 & Sedang & 57 & Rendah \\
\hline & Rataan & 77 & Sedang & 70 & Sedang \\
\hline
\end{tabular}

Tidak terdapat perbedaan kemampuan awal siswa kelas eksperimen dan siswa kelas kontrol. 
Tabel 11. Data Pemahaman Konsep Matematis Siswa

\begin{tabular}{|c|c|c|c|c|c|c|}
\hline & \multicolumn{3}{|c|}{ Kelas Eksperimen } & \multicolumn{3}{c|}{ Kelas Kontrol } \\
\hline & $\mathbf{T}$ & $\mathbf{S}$ & $\mathbf{R}$ & $\mathbf{T}$ & $\mathbf{S}$ & $\mathbf{R}$ \\
\hline $\mathbf{N}$ & 14 & 5 & 12 & 12 & 8 & 5 \\
\hline $\bar{X}$ & 83 & 74 & 63 & 73 & 64 & 50 \\
\hline $\bar{X}$ & \multicolumn{3}{|c|}{73,87} & \multicolumn{3}{c|}{65,6} \\
\hline
\end{tabular}

Tidak terdapat efek/pengaruh interaksi antara model pembelajaran dan kemampuan awal matematis siswa terhadap pemahaman konsep matematis siswa. Dengan demikian model pembelajaran tidak mempengaruhi kemampuan pemahaman konsep matematis siwa dan juga kemampuan pemahaman konsep matematis siswa tidak bergantung pada peringkat kemampuan awal matematis siswa.Semakin tinggi kemampuan awal matematis siswa maka tidak akan semakin pula tinggi kemampuan pemahaman konsep matematisnya. Sebaliknya semakin rendah kemampuan awal siswa maka tidak akan semakin rendah pula kemampuan pemahaman konsep matematisnya.

\section{KESIMPULAN}

Berdasarkan hasil pengolahan data dan analisis data yang diperoleh dari penelitian yang dilakukan mengenai "Pengaruh Penerapan Model Pembelajaran Group Investigation Terhadap Pemahaman Konsep Matematis Ditinjau Dari Kemampuan Awal Matematis Siswa Madrasah Tsanawiyah Darul Qur'an", maka dapat disimpulkan bahwa: 1) Terdapat perbedaan pemahaman konsep matematis antara siswa yang mengikuti pembelajaran Group Investigation dengan siswa yang mengikuti pembelajaran langsung. Dengan hasil penelitian kelas eksperimen lebih tinggi nilai ratarata dari pada kelas kontrol. 2) Tidak terdapat perbedaan kemampuan awal siswa kelas eksperimen dan siswa kelas kontrol. 3) Tidak terdapat efek/pengaruh interaksi antara strategi pembelajaran dengan kemampuan awal matematis siswa terhadap pemahaman konsep matematis siswa.

Berdasarkan hasil dari penelitian, peneliti dapat memberikan rekomendasi sebagai berikut: 1) Dalam pembuatan soal harus sesuai dengan indikator pemahaman konsep. 2) Langkah-langkah model pembelajaran Group Investigation pada RPP harus sesuai dengan sumber yang ada. 3) Unuk menghindari biasnya hasil posttest, siswa perlu dibiasakan terlebih dahulu secara sehari-hari dengan soal-soal yang terkait pehaman konsep dan hal ini perlu muncul di RPP.

\section{REFERENSI}

Depertemen Pendidikan Nasional. (2006). Model Penilaian Kelas. Badan Standar Nasional Pendidikan.

Hamalik, O. (2008). Perencanaa Pengajaran Berdasarkan Pendekatan Sistem. Jakarta: Bumi Aksar.

Hamdani. (2011). Strategi Belajar Mengajar. Bandung: CV. Pustaka Setia.

Hosnan, M. (2014). Pendekatan Saintifik dan kontekstual dalam Pembelajaran Abad 21. Bogor: Ghalia Indonesia.

Huda, M. (2014). Model-Model Pengajaran dan Pembelajaran. Yogyakarta: Pustaka Belajar.

Muhandaz, R. Trisnawita, O., \& Risnawati, R. (2018). Pengaruh Model Pembelajaran Course Review

Horay terhadap Kemampuan Pemahaman Konsep Matematis Berdasarkan Kemandirian Belajar

Siswa SMK Pekanbaru. JURING (Journal for Research in Mathematics Learning), 1(2), 137-146

Purwanto, N. (2012). Prinsip-prinsip dan Teknik Evaluasi Pengajaran. Bandung: Remaja Persada karya Sanjaya, W. (2006). Strategi Pembelajaran. Jakarta: Kencana Prenada Media Group.

Sari, R. Suhandri, S. \& Nufus, H. (2018). Pengaruh Penerapan Model Pembelajaran Quantum Teachingterhadap Pemahaman Konsep Matematis Berdasarkan Minat Belajar Matematika Siswa 
Sekolah Menengah Pertama Kampar. JURING (Journal for Research in Mathematics Learning), 1(2), $127-136$

Sugiyono. (2012). Statistika untuk Penelitian, Bandung: Alfabeta.

Suyatno. (2009). Menjelajah pembelajaran inovatif. Sidoarjo: Masmedia Buana Pustaka.

Wahidah, N., Hasanuddin, H., Hartono, H. (2018). Pengembangan Lembar Kerja Siswa dengan Model Pembelajaran Koperatif Tipe Kreatif-Produktif untuk Memfasilitasi Kemampuan Pemahaman Konsep Matematis Siswa SMP Negeri 21 Pekanbaru. JURING Journal for Research in Mathematics Learning), 1(1), 79-90 